Chapter 10

\title{
The Influence of Alloy Element on Magnesium for Electronic Devices Applications - A Review
}

\author{
Waldemar Alfredo Monteiro \\ Additional information is available at the end of the chapter \\ http://dx.doi.org/10.5772/58460
}

\section{Introduction}

This chapter presents a concise feature on past, present and the fast emerging future trends of the effective use of magnesium alloys in electronic industries. Magnesium's furthermost potential places on all types of handheld electronic devices, from mobile phones to MP3 players, cameras to smartphones, especially with the emission and interference suppression requirements of electronic devices. A lot of effort has been made to understand some properties required in electronic behavior of magnesium alloys and to have a look on their potential for further use.

To understanding some fundamental mechanism involved in any metallic material processing it is important, for example do not stop thinking about the atomic structure, chemical bonding energy and also electron distribution of the element magnesium (Table 1).

\begin{tabular}{ccc}
\hline Element & Atomic number & Electron configuration \\
\hline Magnesium & 12 & $1 \mathrm{~s}^{2} 2 \mathrm{~s}^{2} 2 \mathrm{p}^{6} 3 \mathrm{~s}^{2}$ \\
\hline
\end{tabular}

Table 1. Electron configurations of Magnesium

The accurate knowledge of electron configuration is particularly related with elastic properties of phases in magnesium alloy (elastic constants, the bulk moduli, shear moduli, Young's moduli and Poisson's ratio). Many of these phases are ductile. Revision involving the states density (DOS), the number of occupied orbitals (Mulliken electron occupation number) and charge density difference support the understanding of the mechanism of structural stability and mechanical properties [1]. 
Magnesium is the lightest of all metals used as the basis for structural alloys. The requirement to reduce the weight of automobile components as a result in part of the introduction of legislation limiting emission has triggered renewed interest in magnesium. A wider use of magnesium base alloys necessitates several parallel programs. These can be classified as alloy development, process development, improvement and design considerations [2].

Magnesium alloys are employed as a replacement for plastics when require adequate thermal conductivity properties. This makes magnesium alloys a better choice in electronic appliances to dissipate heat generated by electronic circuits. These alloys are utilized within TVs, LCDs and PC casings. There are many other better magnesium alloy properties. Magnesium alloys are less resistant to cutting, which makes them easier for rapid machining. The $\mathrm{Mg}$ alloys are superior at electromagnetic interference (EMI) shielding and often used in casings for mobile phones. Magnesium alloys are easily recyclable, ductile and can absorb vibration well. Magnesium alloys also have excellent resistance to corrosion. The alloys resist dents and are less likely to give dents to other metals [3-5].

Magnesium is the perfect material for applications where weight saving is a precedence, as it has the lowest density of all structural metals. Almost as light in weight as plastic, magnesium has the advantage of greater strength and rigidity, along with inherent EMI shielding and full recyclability. The magnesium benefits are: the lightest of all structural metals; excellent stiffness \& strength-to-weight ratio; exceptional EMI shielding properties; high electrical and thermal conductivity; withstands high operating temperatures; cost effective versus many engineered thermoplastic materials; high dimensional accuracy and stability; exceptional thinwall capability; good environmental corrosion resistance; good finishing characteristics; fully recyclable, all of these, ideal for electronic devices [6-8].

\section{Elements in magnesium}

There are several magnesium compositions which are currently being explored. Some of the alloys are at more developed research stages than others, and each alloy has been tailored for specific applications as previously mentioned. Pure magnesium has been used, as well as other elements including $\mathrm{Zn}, \mathrm{Mn}, \mathrm{Al}, \mathrm{Ca}, \mathrm{Li}, \mathrm{Zr}, \mathrm{Y}$, and rare earth metals (RE). These within the $\mathrm{Mg}$ matrix create different mechanical and physical properties. If the alloying element can accomplish the metallurgical principle of developing solid solution, then solid solution strengthening can be achieved (Table 2).

Solid Solutions are generally stronger than pure metals due to the enhanced crystal structure and the introduction of crystalline defects (for example, dislocations) inside the matrix, but generally, with lower electric conductivity compared to the pure metal. This process is known as solid-solution strengthening. The formation of inter-matrix phases improves the strength of the alloy and is referred to as dispersion strengthening. This is the common practice when forming an alloy. Typically, one metal will have larger atoms relative to other constituents within the material and form a ductile phase (matrix) that consists of the major volume for the 


\begin{tabular}{|c|c|c|c|}
\hline $\begin{array}{l}\text { Alloy } \\
\text { description }\end{array}$ & Alloying additions & Basic Uses & Properties and applications \\
\hline AZ91 & $\begin{array}{l}9.0 \% \mathrm{Al}, 0.7 \% \mathrm{Zn}, \\
0.2 \% \mathrm{Mn}\end{array}$ & General casting alloy & $\begin{array}{l}\text { Good castability, good mechanical properties at } \\
\mathrm{T}<150^{\circ} \mathrm{C}\end{array}$ \\
\hline AZ31 & $\begin{array}{l}3.0 \% \mathrm{Al}, 1.0 \% \mathrm{Zn}, \\
0.13 \% \mathrm{Mn}\end{array}$ & $\begin{array}{l}\text { Wrought magnesium } \\
\text { products }\end{array}$ & Good extrusion alloy \\
\hline AM60 & $6.0 \% \mathrm{Al}, 0.15 \% \mathrm{Mn}$ & $\begin{array}{l}\text { High pressure die-casting } \\
\text { alloy }\end{array}$ & $\begin{array}{l}\text { Better toughness and ductility than AZ91. } \\
\text { Automotive structural applications }\end{array}$ \\
\hline AM50 & Mg-Al system & General casting alloy & $\begin{array}{l}\text { Good strength, ductility, energy absorption } \\
\text { properties and castability }\end{array}$ \\
\hline AM20 & Mg-Al system & Casting alloy & High ductility, toughness, poor die-castability \\
\hline AE42 & $\begin{array}{l}\mathrm{Mg}-4 \mathrm{at} \% \mathrm{Al}-2 \mathrm{at} \\
\% \text { rare earths }\end{array}$ & General casting alloy & Low castability, good creep behavior \\
\hline AE44 & $\begin{array}{l}\text { Mg-Al-rare earth } \\
\text { (RE) system }\end{array}$ & General casting alloy & Better creep behavior and castability than AE42 \\
\hline ZE41 & $\begin{array}{l}4.2 \% \mathrm{Zn}, 1.2 \% \mathrm{RE}, \\
0.7 \% \mathrm{Zr}\end{array}$ & Casting alloy & $\begin{array}{l}\text { RE addition improves creep strength at superior } \\
\text { temperatures. Pressure tight. }\end{array}$ \\
\hline AS21 & Mg-Al-Si system & Casting alloy & For use at temperatures in excess of $120^{\circ} \mathrm{C}$ \\
\hline AS41 & $4.2 \% \mathrm{Al}, 1.0 \% \mathrm{Si}$ & General casting alloy & $\begin{array}{l}\text { Better creep resistance than AZ91 at elevated } \\
\text { temperatures, lower strength }\end{array}$ \\
\hline AJ62 & Mg-Al-Sr system & $\begin{array}{l}\text { High pressure die-casting } \\
\text { (HPDC) }\end{array}$ & $\begin{array}{l}\text { Superior castability, corrosion resistance and } \\
\text { creep behavior; good thermal and mechanical } \\
\text { strength }\end{array}$ \\
\hline MRI 153M & Mg-Al-Ca-Sr system & Casting alloy & For high temperatures applications up to $150^{\circ} \mathrm{C}$ \\
\hline MRI230D & Mg-Al-Ca-Sr system & Casting alloy & For high temperatures applications up to $190^{\circ} \mathrm{C}$ \\
\hline
\end{tabular}

Table 2. Commercial magnesium alloys and their applications [9]

alloy. The second metal added to the alloy consists of smaller atoms that are usually both stronger and harder relative to the mechanical properties [10 - 15].

When two metals are mixed together to obtaining an alloy, the resulting material is dispersion strengthened (exist grain boundaries between two or more phases). When dispersion strengthening occurs, micro-scaled precipitates usually form within the grain boundaries, which further strengthen the material as the precipitates prevent slipping of the dislocations or other crystal defects within the grain or phase. Such action induced by heat treatment within the manufacturing process is referred to as precipitation hardening [10 - 15].

Refined magnesium almost always has trace amounts of other impurity elements. These impurities result from the natural composition of magnesium found within the earth, as well as the casting and refining processes used. The degree of impurities after the refining process 
is dependent upon the efficiency of the refining process itself. Elements currently found within the magnesium include copper $(\mathrm{Cu})$, beryllium $(\mathrm{Be})$, nickel $(\mathrm{Ni})$, and iron $(\mathrm{Fe})$. Standards for characteristic element inclusion in Magnesium are: 4 ppm Be, 100-300 ppm Cu, 35-50 ppm Fe, and 20-50 ppm Ni (weight percent). Other elements may be existent and are referred to as general alloying elements. Always the amount of these impurities should be controlled for any application, especially if pure magnesium is desired [13, $15-19]$.

Magnesium-zirconium-aluminum alloys are utilized in relatively low volume applications where they are processed by sand or lost-wax casting, or wrought products by extrusion or forging. The Mg-Al-Zn group of alloys is the most common alloying elements for room temperature applications. Cerium and zirconium (without aluminium) are used for elevated temperatures and form the $\mathrm{Mg}-\mathrm{Zn}-\mathrm{Zr}$ group (Table 2). Cerium is added to improve strength at the temperatures of $260^{\circ} \mathrm{C}$ to $370^{\circ} \mathrm{C}$. Aluminium is the most effective ingredient in improving results. As little as $2 \%$ to $10 \%$ aluminium with minor additions of zinc and manganese increases strength and hardness, at the expense of less ductility, without harming weldability and making the alloy receptive to heat treatment [9].

This low density of magnesium and alloys has stimulated the use in helicopter parts, auto parts and portable electronic appliance parts. Magnesium alloys are utilized in many engineering applications where having light weight is a significant advantage. Magnesium alloys have always been attractive to designers due to their low density, only two thirds that of aluminum. This has been a major factor in the widespread use of magnesium alloy castings and wrought products [20-22].

A further requirement in recent years due to superior corrosion performance and dramatic improvements have been demonstrated for new magnesium alloys. Ultra-light magnesium alloys with excellent specific properties potentially met the present demands for lighter and reliable construction. There is a fast emerging trend towards using the lightweight materials and structures principally for electronic devices. The second principal magnesium application field are in electronic devices; see as example in Table 3 for electronic rain sensor housing.

\begin{tabular}{lll}
\hline Magnesium Alloy & AZ91D & AM60Bt \\
\hline Alloy Element (\%) & & \\
\hline Aluminum & $8.3-9.7$ & $5.5-6.5$ \\
\hline Manganese & $0.15-0.5$ & $0.24-0.6$ \\
\hline Zinc & $0.35-1.0$ & 0.22 (max) \\
\hline Silicon (max) & 0.1 & 0.1 \\
\hline Copper $(\max )$ & 0.03 & 0.01 \\
\hline Nickel $(\max )$ & 0.002 & 0.002 \\
\hline Iron $(\max )$ & 0.005 & 0.005 \\
\hline Other Metallic $(\max )$ & 0.02 & 0.02 \\
\hline Magnesium & remainder & Remainder \\
\hline
\end{tabular}

Table 3. Magnesium Alloys for Electronic Rain Sensor Housing 
The AZ91D is a high-purity alloy which has excellent corrosion resistance. As mentioned before, due to low weight, good mechanical and electrical properties, magnesium is widely used for manufacturing of mobile phones, laptop computers, cameras, and other electronic components. Since its too low mechanical strength, pure magnesium must be alloyed with other elements, which confer improved properties. The tendency has been for an increase in the use of magnesium die castings and examples are computer housings and mobile telephone cases where lightness, suitability for thin wall casting and the characteristic of electromagnetic shielding are particular advantages [10, 12, 15, 16].

Magnesium alloys containing more than $1.5 \% \mathrm{Al}$ are susceptible to stress corrosion and must be stress relieved after welding. Iron, copper and nickel are considered impurities to be limited because they degrade the corrosion resistance of magnesium alloys. Zinc combined with aluminium overcomes detrimental corrosive effects of iron and nickel impurities that may be present in magnesium alloys. The higher the Zn content (over 1\%) the higher the hot shortness, causing weld cracking. Manganese improves yield strength and the saltwater resistance of magnesium alloys [10, 12, 15, 16].

Particularly for electronic devices there is alertness due to the some disadvantages of Mg alloys: high reactivity in the molten state, galvanic corrosion resistance, fire hazard, inferior fatigue and creep. The design of the Mg alloy parts is important for adequate drainage, to prevent the accumulation of corrosive substances, such as water/moisture. Iron, nickel and copper reduce the corrosion resistance of $\mathrm{Mg}$ alloys. Thus, during the processing of hot/molten $\mathrm{Mg}$ alloys, the metal must be shielded by inert gas or flux to overcome fire risk. In machining process of Mg alloys, the fire hazard/risk can be eliminated by avoiding fine cuts, dull tools, and high speeds, using proper tool design to avoid heat buildup, avoiding the accumulation of chips and dust on machines and cloths, and using coolants [10, 12, 15, 16].

Substantial research is still needed on magnesium processing, alloy development, joining, surface treatment, corrosion resistance and mechanical properties improvement to achieve future goals in all requests areas and actually, the amount of greenhouse gases [17]. Production and application technologies must be cost effective for magnesium alloys to make magnesium alloys an economically viable alternative for the automotive industry. For example the automobile contained around $20 \mathrm{~kg}$ of magnesium in powertrain and during its peak production consumption of magnesium reached 42,000 ton per year [6].

The global magnesium consumption is projected to rise in 2015 more than $1.3 \mathrm{Mt}$. Its single largest use, die-cast alloys for the automotive industry, is expected to show the fastest rate of about $10 \%$ p.a., underpinned largely by Chinese vehicle production. The use of magnesium cast alloys in computers, communications and consumer electronics, principally for injection molded housings, and uses for the desulphurization of steel, is also expected to grow strongly [23].

The major step for improving the corrosion resistance of magnesium alloys was the introduction of high purity alloys. Alloying can further improve the general corrosion behavior, but it does not change galvanic corrosion problems if magnesium is in contact with another metal and an electrolyte. The galvanic corrosion problem can only be solved by proper coating 
systems. Different coating methods are used to increase the corrosion resistance of magnesium alloys. Problems with contact corrosion can be minimized, on the one hand, by useful measures and, on the other hand, by an appropriate choice of material couple or the use of protective coatings. Aluminum coating is also used for magnesium alloys using aluminum vapor deposition and finish treatment by resin coating. The $\mathrm{Al}$ coating provides high corrosion resistance for magnesium alloys with various metallic sheens $[7,13,15,16]$.

\section{The background for improvement - Electronic applications}

Lightweight, strong and durable, magnesium alloy parts are expanding their sphere of influence into professional grade high-end appliance and electronics products. Manufacturers who are looking for ways to improve quality and reliability are fine tuning product capabilities by adding the precision and versatility of magnesium components. Magnesium is chosen for top of-the-line products that offer superior staying power, and rugged structural and mechanical properties that are unmatched by other materials. Magnesium's inherent ability to shield internal technology from electromagnetic interference and radio frequency interference (EMI/RFI) make it the ideal light metal for housing electronics.

Stand mixer has long been considered the industry standard in countertop kitchen appliances that chefs, cooks and bakers everywhere count on to mix and blend their favorite recipes. The mixer's direct drive transmission with all-metal construction is housed in magnesium. Every part of the stand mixer, from its magnesium housed transmission, to its professional-level motor, to its spiral dough hook is equipped for high performance. Product engineers,(for example, from KitchenAid, Greenville, Ohio, USA), selected magnesium for the stand mixer's transmission housing because the magnesium housing withstands higher temperatures and may be molded without any secondary operations, without machining for the bearing pockets and locator pins. The mixer's designers also cite magnesium as a very stable material that offers excellent part-to-part repeatability. A major benefit for the heavy-duty stand mixer is that the magnesium transmission housing may be subjected to higher loads and temperatures than the previously used thermostat plastic.

For this type of equipment, in a high-load and high-temperature application, magnesium was chosen over cast aluminum because of its ability to be molded, since cast aluminum or cast zinc would require secondary machining.

Studies have shown that one of the most important factors in determining corrosion of a magnesium implant is dependent on the purity of the material. It has been well noted that $\mathrm{Fe}$, $\mathrm{Ni}$, and $\mathrm{Cu}$ are three critical corrosion elements, which when present within magnesium significantly increase the rate of corrosion. These metals are harmful because of their low solidsolubility limits and because they serve as active cathodic sites within the material itself. Cathodic sites are regions within the material where reduction reactions occur. These regions are essential to the formation of a corrosion cell, and are generally involved with absorbing electrons produced from oxidizing materials (anodic site). At cathodic sites, nearly no material serving as the cathode is lost $[13,15,16]$. 
The solid-solubility limit of a material is the extent to which an alloying element will dissolve in base materials without forming a different phase. Generally, the higher the solid solubility limit the more likely the alloying element can homogenously disperse within a material. Whereas, low solid-solubility limits will more readily form separate phases within the material. For example, an alloy of $\mathrm{Mg}$-Cu would more likely be separated into two different phases, a copper phase and a magnesium phase. This can be seen in classical cases of pitting corrosion formation.

Magnesium materials exposed to atmospheric conditions will develop a thin gray layer on its surface, which is partially protective. Ions in general are considered to be corrosive if they have the ability to breakdown the protective layer on the surface of magnesium, such as chlorides and oxidizing salts. Passivating elements like chromates, vanadates, and phosphates have been used to retard corrosion because of their ability to form a passive surface film [10-13]

Magnesium is a metal that readily corrodes in the presence of water. Atmospheric conditions contain certain levels of water content in the form of humidity, and the corrosion of magnesium alloys increases with relative humidity. The corrosion of magnesium increases significantly when exposed to pure water. This is especially true to evaluate the corrosion behavior of implantable medical devices manufactured from magnesium based materials. There are several different types of alloying elements used in magnesium based materials in an attempt to control their corrosion properties and feasibility for biomaterial implant. Elements like Mn, $\mathrm{Cu}, \mathrm{Al}, \mathrm{Ca}, \mathrm{Zr}, \mathrm{Gd}$, and $\mathrm{Zn}$ have all been explored [11-14].

Magnesium alloy AZ91D is used, for example, by Phillips Magnesium Injection Molding, Eau Claire, Wisconsin, to form 15 different parts (power input mount housing; manifold cover; docking station battery door; RAM access, CMOS, PCMCIA, DVD, computer battery and hard drive doors; bezel for display screen frame and cover for back of display screen; the computer chassis and cover; and the docking station chassis and cover) used in the maintenance support device laptop, made by VT Miltope, Hope Hull, Alabama, has high-performance computing. Magnesium's advantages include high strength, stiffness, durability, and superior impact resistance, making the laptop parts 20 times stronger than typical thermoplastics. The magnesium alloy housings and enclosures provide effective EMI shielding without using fillers, with an applied conversion coating. Magnesium's EMI shielding ability is critical during military field operations, since the magnesium parts protect the laptop from radiated and conducted emissions, electromagnetic pulses and radiation hazards, withstanding extreme temperatures, solar radiation, shock, transportation vibration, altitude, rain, humidity, sand, dust, and salt fog [24-26].

Some especial consumer camcorder is housed in a magnesium alloy frame, making the handheld unit much lighter and easier to hold. The magnesium frame enclosure houses a host of high-tech electronics, and includes features such as a backlit 3D button enabling easy switching from 2D to 3D mode, 5 times optical zoom, the ability to access the battery port and SD card slot while mounted on a tripod, and sports a mottled finish for an easier grip and high-end look.

Another good example is a professional video camera - magnesium and aluminum co-star as die-cast precision components for the out-of-studio camera's base, chassis, outer panels and 
internal sub-assemblies. The electronic engineers required lightweight, high-strength components to protect the advanced CCD image sensors, digital video processing and digital control systems inside. Magnesium industries was chosen these demands by die casting the portable video camera's housing components using magnesium AZ91D and aluminum 380 alloys for the camera's chassis, base, case panels and related parts [25-26].

Magnesium castings form the front-end chassis, frame, handle, and right and left cover panels and base, while aluminum takes the back-end role of left, right and top cover panels and back frame. An ingenious internal magnesium/front and aluminum/rear stop block system enables a miniature camera to slide into and out of the main video camera's shell, allowing versatile options for televising in-studio or remotely.

The Integrated Imaging Capsule allows the virtual plug-in mini-camera to nest inside the studio camera head or the portable camera head, delivering equally precise advanced imaging from each camera version. The die-cast rigid magnesium chassis and case panels provide the internal electronics with built-in EMI/RFI shielding. Inside, the chassis is center-gated, with walls cast to $1.016 \mathrm{~mm}$. Outside panels are cast to net shape and some parts receive secondary machining, including: CNC hole drilling and tapping; minimum vibratory noise; hand cleaning; coating; final powder coat or wet paint [25-26].

Since the 90 years the electronics industries try to obtain a new type of clean magnesium alloy known as eco-magnesium alloy [27-28]. Finally in 2012, one of these real advances was developed for LG by the Korea Institute of Industrial Technology (KITECH) with funding from the Korean government, for parts being produced for all of its mobile phones.

In special LG trusts on magnesium parts for its mobile phones due to its lightness and hardness, but sought out a way to mass-produce the magnesium parts using an environmentally responsible method. The die casting process used to produce Eco-Magnesium components virtually eliminates use of damaging sulfur-hexafluoride (SF6) cover gases. As a result, LG plans a reduction in greenhouse gas emissions by a factor of approximately 24,000 during the die casting process without affecting product quality $[29,30]$.

Technical texts of LG indicate that is considering the use of Eco-Magnesium as soon as possible to other portable devices, such as laptops and tablets. The potential environmental benefits for expanding Eco-Magnesium use to additional electronic devices are substantial, given the company's projections for massive reductions in greenhouse gas emissions from their mobile phone production alone. Globally, manufacturers in key industries are seeking environmentally sound ways to produce and form magnesium alloys. Magnesium's spectrum of sustainable product possibilities is expected to broaden and grow, as new forming and processing technologies enable the use of magnesium parts in a host of new high-performance products $[29,30]$.

Within the last fifteen years several heavy magnesium parts have been assembled in passenger cars, such as gearbox housings and crankcases. Reasons are the new heat resistant alloys and the growing duty of automotive constructors to reduce the vehicles weight and in that way $\mathrm{CO}_{2}$ emission (regulation). The rising quantity of magnesium in automobiles will result in an increasing amount of post-consumer scrap. So far magnesium recycling for magnesium alloy 
production is done only for clean scrap. Clean in this regard means "free from impurities", contaminations and sorted according to a chemical composition or a single phase alloy [25-28].

For automotive post-consumer scrap the materials quality strongly depends on the way endof-life vehicles are treated. Up to date automotive manufacturers have no uniform recycling system for end-of-life vehicles. By proper dismantling of old cars, the bigger magnesium components could be collected and possibly treated similar to class 1 scrap.

So far the biggest part of old cars has been shredded and it is probable that this practice will be continued for reasons of economy. The magnesium fraction can be segregated from the nonmagnetic shredder fraction via sink float separation and eddy current separation. A further separation according to chemical composition is claimed to be feasible. Still another problem is unsolved. Due to coatings on magnesium components or aluminium alloy contaminations it is expected that magnesium post-consumer scrap will be enriched with $\mathrm{Cu}$, Fe and Ni during remelting [30].

Eco-conscious design innovations require materials that support and facilitate optimal energy efficiency and longer product life cycles. Magnesium alloys achieve this while being fully reusable and recyclable. From Light Emitting Diode (LED) lighting to lighter vehicles that reduce an engine's load, to housing longer-life batteries in computers and electric personal transport, magnesium is turning into the designer's most versatile material choice to improve product functionality and develop user mobility with greater energy efficiency and environmental benefits.

A light-emitting diode (LED) is a two-lead semiconductor light source that resembles a basic pn-junction diode, except that an LED also emits light. When a LED's anode lead has a voltage that is more positive than its cathode lead by at least the LED's forward voltage drop, current flows and electrons are able to recombine with holes within the device, releasing energy in the form of photons. This effect is called electroluminescence, and the color of the light (corresponding to the energy of the photon) is determined by the energy band gap of the semiconductor $[31,32]$.

The light's entire housing is constructed of magnesium alloy AZ91D by AltusLumen, Hong Kong, China [31, 32]. The portable LED is a convenient rechargeable lithium-ion battery light with intelligent power management, featuring a three-dimensional hinge that adjusts to any lighting angle. The ultra-bright and efficient runs for several hours on a single charge, and may be charged by solar panel with an optional solar charger because magnesium conducts heat generated by the LED light away from the LED bulb, extending its usable life.

In addition, only magnesium provides the strength required to produce the unique feature of a three-dimensional swivel hinge. The LED light component is screwed into the magnesium housing, with upper and lower housings joined by a metal pin, force fitting upper and lower housings together. The magnesium housing is cast via injection. After parts are injected, CNC machining removes extra material. Holes are then drilled into the housing for mounting and the magnesium is powder coat painted. The pocket-size portable light follows the company's guiding sustainability principles that include energy efficiency, using renewable energy, and choosing materials that are recycled and recyclable (AZ91D). 
Magnesium is one of the few materials that can be continuously recycled without degradation. Magnesium is easier to recycle and its value makes it an attractive material to recycle. Another company also chooses magnesium alloy housing for its energy efficient LED warm-white and pure-white frosted soft flood lights (LEDtronics, Inc., Torrance, California) and maintains high shock and vibration resistance.

Thermal management performed using the magnesium housing offers the best heat sinks, even better than copper. The long-life LED flood light is used for signage, architectural and landscape lighting, security, aviation, industrial equipment, medical, and theatrical lighting. The magnesium swivel hinge and foldable tripod stand make the TRI-L LED portable light a hands free, go anywhere device. The Parabolic Aluminized Reflector (PAR) 38 Series LED flood light features a magnesium alloy body in a solid-state design that facilitates energy savings of up to 85 percent compared to incandescent flood lights [33].

In the modern market, small and portable electronics are trending increasing. The demand for compact devices that can be easily transported is successful and magnesium is often a key component in meeting this demand. Many magnesium alloys being used to replace plastics are just as light, but they are much stronger and more durable.

Magnesium is also better in regards to heat transfer and dissipation as well as its ability to shield electromagnetic and radio frequency interference. Many electronics require parts or casings with multifarious shapes which are possible with magnesium. Camera, cell phone, laptop and portable media device lodgings are all common applications in addition to arms of hard drives $[33,34]$.

Electroplated plastics might look like metals but, because the underlying plastic substrate is thermally non-conductive, they do not feel like metals.

This simple matter of aesthetics often disappoints consumers when it is realized, when touched, that an outwardly metallic looking item clearly isn't what it was thought to be. Because it is a conductive metal, AM-lite ${ }^{\circledR}$ does have a "metallic feel" and so is more attractive to customers. AM-lite ${ }^{\circledR}$ has a much higher stiffness, yield strength and creep strength than unreinforced plastics thus allowing improved thin section light weight designs. The alloy's electrical and thermal conductivity, and EMS shielding, is also important for the design of consumer electronics such as mobile phones and laptop computers [34].

\section{Author details}

Waldemar Alfredo Monteiro ${ }^{1,2}$

1 Materials Science and Technology Center -Nuclear and EnergyResearch Institute, São Paulo, $\mathrm{SP}_{\text {, }}$ Brazil

2 School of Engineering - Presbyterian Mackenzie University, São Paulo, Brazil 


\section{References}

[1] Pingli M, Bo Y, Zheng L, Feng W, Yang J, First-principles calculations of structural, elastic and electronic properties of AB2 type intermetallics in $\mathrm{Mg}-\mathrm{Zn}-\mathrm{Ca}-\mathrm{Cu}$ alloy", Journal of Magnesium and Alloys 1 (2013) 256-262

[2] Mordike BL \& Ebert T, Materials Science and Engineering A302 (2001) 37-45.

[3] Kojima Yo, Platform Science and Technology for Advanced Magnesium Alloys, Magnesium Alloys 2000, Materials Science Forum, Volumes 350-351), page 3 - 19, doi: 10.4028/www.scientific.net/MSF.350-351

[4] Duffy L, Materials World, Vol 4. No 3, pp. 127-30, 1996.

[5] Dunlop G.; Abbott T.; Murray M.; Bettles C.; Gibson M.; in Proceedings International Magnesium Association World Conference, Beijing, IMA 2006, p. 24 - 33

[6] http://www.magnesium-elektron.com/markets-applications.asp?ID=7, 23/02/2014.

[7] Kainer K. U., Dieringa H., Dietzel W., Hort N. and Blawert C., The Use of Magnesium Alloys; Past, Present and Future, Pekguleryuz M.O. and Mackenzie L.W.F. eds. (2006) Magnesium Technology in the Global Age 2006, Metallurgical Society of CIM, Montreal Canada. 2006 Magnesium Technology in the Global Age

[8] Gibson M. A., Bettles C. J., Murray M.T., Dunlop G.L., Cashion S.P., “AM-HP2: A New Magnesium Alloy with Improved Diecastability and Creep Strength for Powertrain Applications", $13^{\text {th }}$ Magnesium Automotive and End User Seminar, Aalen, $22^{\text {nd- } 23^{\text {rd }}}$ September 2005.

[9] Kulekci M. K., Magnesium and its alloys applications in automotive industry, Int. J. Adv. Manuf. Technol. (2008) 39: 851-865

[10] Eliezer D., Aghion E., Froes F.H., Magnesium Science, Technology and Applications, Advanced Performance Materials 5, 201-212 (1998) Kluwer Academic Publishers, The Netherlands.

[11] Polmear, I.J., Light alloys: metallurgy of the light metals, Third edition, 1995, Arnold, London, ISBN 0-340-63207.

[12] Smith, W.F., Structure and properties of engineering alloys, $2^{\text {nd }}$ edition, 1993, McGraw-Hill, ISBN 0-70-112829-8.

[13] Kainer, K.U. (Ed), Magnesium Alloys and Technology, DMG, 2003, Wiley-VCH, ISBN 3-527-30256-5.

[14] Siobhan F, An Overview of Magnesium based Alloys for Aerospace and Automotive Applications, MSc, Rensselaer Polytechnic Institute, Hartford, CT, August, 2012.

[15] Avedesian, M.M., Baker, H., ASM SPECIALTY HANDBOOK, Magnesium and magnesium alloys, 1999, ISBN 0-87170-657-1. 
[16] E. Aghion, B. Bronfin, Magnesium Alloys Development towards the $21^{\text {st }}$ Century, Magnesium Alloys 2000, Materials Science Forum, Volumes 350-351), page 19 - 31, doi:10.4028/www.scientific.net/MSF.350-351

[17] Ehrenberger S., Schmid S., Friedrich H., Magnesium production and automotive applications: Life-cycle analysis focusing on greenhouse gases, 16. Magnesium Abnehmer-und Automotive Seminar 2008 in Aalen (http://www.efm-aalen.de/PDF/ Ehrenberger_magnesiumx.pdf)

[18] Kubota K., Mabuchi M., Higashi K., Review Processing and mechanical properties of fine-grained magnesium alloys, Journal of Materials Science, Volume 34, Issue 10, pp 2255-2262.

[19] Labelle P., “Compilation of AJ62A Typical Alloy Properties”, Noranda Inc., December 2004.

[20] Dieringa H., Bohlen J., Hort N., Letzig D., Kainer K. U., Advances in Manufacturing Processes for Magnesium Alloys, Beals, R. S., Luo, AA, Neelameggham, NR, Pekguleryuz, MO, eds (2007) Magnesium Technology 2007, Orlando, FL 2007 Magnesium Technology

[21] Avraham S., Maoz Y., Bamberger M., Structural Evolution in Mg-Al Alloys, Beals, RS, Luo, AA, Neelameggham, NR, Pekguleryuz, MO, eds (2007) Magnesium Technology 2007, Orlando, FL, 2007 Magnesium Technology

[22] Longanbach S. C., Knittel K., Lee A., Boehlert C. J, Processing-Microstructure-Property Relationships of Magnesium Alloys Containing Zr and/or B, Beals, RS, Luo, AA, Neelameggham, NR, Pekguleryuz, MO, eds (2007) Magnesium Technology 2007, Orlando, FL 2007 Magnesium Technology

[23] http://www.chinamagnesiumcorporation.com/our-business/magnesium-overview.

[24] Barker E., Li D., Sun X., and Khaleel M., Microstructure Modeling of Magnesium Alloys for Engineering Property Prediction, Mathaudhu, SN, Sillekens, WH, Neelameggham N.R., Hort N, eds (2012) TMS Magnesium Technology 2012, Orlando, FL, USA, 2012 Magnesium Technology

[25] Ulrike G. K. Wegst, Michael F. Ashby, The development and use of a methodology for the Environmentally-Conscious selection of Materials, Third Biennial World Conference on Integrated Design and Process Technology (IDPT), 6-9 July 1998, Berlin, Germany (Proceedings Volume 5, pp. 88-93)

[26] Aghion E., Bronfin B., Friedrich H. and Rubinovich Z., "The Environmental Impact of New Magnesium Alloys on the Transportation Industry", Magnesium Technology 2004, ed. A.A. Luo (Warrendale, PA: The Minerals, Metals \& Materials Society, 2004), 167-172.

[27] Ninomiya R., Kamado S., Kojima Y, Morinago M., An Electronic Approach to the Prediction of the Mechanical Properties and the Design of Magnesium Alloys, Mor- 
dike, BL, Kainer, KU eds (1998) Magnesium Alloys and their Applications, Hamburg, Germany, 1998 Magnesium Alloys and their Applications

[28] Su X., Li D.J., Zeng X.Q., Wang Y.X., Cheng L.F., Ding W.J., Elastic Properties and Electronic Structures of Mg- $\operatorname{Re}(\operatorname{Re}=S m, Y)$ Alloys Studied by First Principle Calculation Principle Calculation, Poole, W. J. and Kainer, K. U., eds (2012), Proceedings of the 9th International Conference on Magnesium Alloy and Their Applications, July 8-12, 2012, Vancouver, BC, Canada, 9th International Conference on Magnesium Alloys and Their Applications.

[29] http://news.cnet.com/8301-17938_105-20024756-1.html, 23/11/ 2012.

[30] http://www.lg.com/global/press-release/article/lg-to-utilize-only-cleaner-eco-magnesium-in-all-mobile-devices-by-2012.jsp, 18/06/2013.

[31] Fechner D. et al. Sci. China Ser. E-Tech Sci. Jan. 2009, vol. 52 no. 1 148-154

[32] http://www.candlepowerforums.com/vb/showthread.php?226594-AltusLumenPAD-L-Review-Portable-Flood-Light, 23/01/2014.

[33] http://www.intlmag.org, 18/01/2014.

[34] http://www.amlite-lighting.com, 17/10/2013. 
